\title{
Students' Perceptions of E-learning During Covid-19 Pandemic
}

\author{
Angga Hidayat \\ Universitas Pamulang \\ angga1203hidayat@gmail.com
}

\begin{abstract}
The objectives of the study are (1) to investigate students' perceptions of the use of e-learning during covid-19 quarantine in accounting department at Pamulang University, (2) to investigate e-learning motivation during covid-19 quarantine in accounting department at Pamulang University. The research is an ex-post facto study conducted in accounting deparment at Pamulang University. Variables in the study consist of independent variable and dependent variable respectively namely students' perceptions of the use of e-learning during covid-19 quarantine and e-learning motivation during covid-19 quarantine. Data obtained from questionnaire about students' perceptions and e-learning motivation during covid-19 quarantine are analyzed quantitatively. Students' perceptions of the use of e-learning during covid-19 quarantine in accounting department at Pamulang University is in medium category. E-learning interest during covid-19 quarantine in accounting department at Pamulang University is in medium category.
\end{abstract}

Keywords: Distance Learning Motivation, E-learning, Perception.

\section{Introduction}

E-learning is a technology commonly used in many universities. Universities that have implemented e-learning include University of Indonesia, the Open University, Pamulang University, and many others. The application of e-learning in higher education is inevitable because of very rapid development that affects all fields, including in the field of education (Hidayat, 2019). As a result, to provide students with provisions to be accepted in their future job is by implementing technology in the learning process. Elearning can be used to improve skill of technology.

E-learning has many benefits that can be obtained both by students and by lecturers. One of the benefits is that e-learning can provide opportunities for students to be more active in the learning process. This can be contributed to the fact that students can open wider resources during learning process. Therefore, students can be more independent in learning. Students know what to look for to compare information they receive from lecturers. Students also take the initiative to look for answers to questions they obtain during the learning process. More important than those all above, students are taught to maximaze the use of technology to achieve learning objectives. That being 
said, this is expected to have an impact on students' skills in solving problems in the future.

However, with the rapid development of technology, not all students are ready to utilize technology in the learning process, especially in distance learning. Distance learning must be conducted in a special condition such as in the Covid-19 pandemic quarantine. This pandemic forced all people in various parts of the world to carry out activities at home, including learning. Consequently, all students must study at home. Specifically, another effect is that Commission For The Protection of Children Indonesia received 213 complaints about distance learning implemented by the government. Complaints include tasks that are too heavy and tedious (Adiyudha, 2020). In other words, both students and teachers are not ready to apply distance learning. One of the reasons is that teachers have unappropriate perception (Nikolopoulou \& Gialamas, 2015).

In a circular of Minister of Education and Culture No. 14 of 2020 concerning Implementation of Educational Policy in the Emergency Period Spreading Coronavirus Disease (covid-2019) states that 1. Learning from home through online / distance learning is carried out to provide meaningful learning experiences for students, without being burdened with the demands of completing the entire curriculum achievements for grade promotion and graduation. 2. Learning from home can be focused on life skills education including the Covid-19 pandemic. 3. Learning activities and assignments Learning from home can vary among students. This can be contributed to the fact that not all students have a complete facility for distance learning. Evidence or products of Learning Activities from Home are given qualitative and useful feedback from the teacher, without being required to give quantitative scores.

Based on the circular above, there are differences in teacher perceptions in implementing distance learning. Many teachers do not have the skills to maximize technology, especially teachers in remote areas (Hidayat \& Sadewa, 2020). Teachers only give assignments without paying attention to meaningful learning experiences for students. In addition, not a few teachers who do not pay attention to learning vary based on students' interest in learning. As a result, students also consider that distance learning is boring and burdensome (Pavlovic, Vugdelija \& Kojic, 2015). This perception is not only experienced by elementary school students through high school, but also by college 
students (Jury, et. 1, 2017). On the other hand, a teacher should have a role to develop the thinking ability of their students (Puspaningtyas, 2019).

Especially for exact sciences, e-learning is still considered inappropriate if applied in subjects hat require high computational abilities such as mathematics and statistics. This is consistent with the results of research conducted by Yaniawati, Kariadinata, Sari, Pramiarsih, \& Mariani (2020) which states that e-learning is difficult to apply to mathematics courses. In addition, the perception of e-learning is also an obstacle in the use of distance learning technology if applied widely in universities. Many students and even lecturers consider that e-learning is not better than learning that is conducted in the class immediately.

To change the perception that e-learning is difficult to apply in universities, elearning motivation must be enhanced (Mustarin \& Wiharto, 2019). Motivation can be triggered by using a variety of interesting features in e-learning. Maximizing these features needs to be used because generally lecturers only use modest features such as discussion forum. There is no doubt that many trainings should be practiced by lecturers. This can affect to interactive e-learning. Moreover, the media used in e-learning are not only from laptops. However, students can also use smartphones to be used in the active learning process. Consequently, it can enhance e-learning motivation.

The development of perception and motivation towards e-learning has been conducted in Pamulang University. Pamulang University is a University located in South Tangerang and has been implementing e-learning since 2016. All departments and all courses have applied blended learning. Therefore, research related to e-learning need to be conducted in Pamulang University because the University has been practicing distance learning for almost 5 years.

Based on the description above, researcher should conduct a study regarding the perception of the use of e-learning as an effort to increase the e-learning interest of students in accounting department at Pamulang University. Objective of this study is to investigate student' perceptions of the use of e-learning in accounting department at Pamulang University. Another objective is to investigate e-learning interest in accounting department at Pamulang University. 


\section{Research Method}

This research is ex post facto research. The use of this type of research is because the symptoms that arise from the research variables already exist on the respondent without treatment. Actions taken to enhance student interest through the application of elearning program. This research is conducted at accounting department in Pamulang University.

Variables of the study consist of independent and dependent variable respectively namely students' perceptions of the use of e-learning during covid-19 quarantine and student interest in e-learning during covid-19 quarantine. The data collection techniques conducted in this study are as following: 1) Data about students' perceptions of Elearning during Covid-19 Quarantine is taken using Likert scale. 2) Data about student interests in E-learning is taken using a Likert scale.

Research instruments used by researcher in this study as follows: 1) Questionnaire about students' perceptions of the use of E-learning during Covid-19 quarantine is used to obtain data about students' perceptions about e-learning during covid-19 quarantine. Questionnaire indicators of students' perceptions includes perception of easiness, perception of usefulness, and perception of acceptance. 2) Questionnaire about student interest in e-learning. Questionnaire indicators of student interest in e-learning include passionate about learning, interested in learning, interested to teacher, initiative to learn, freshness in learning, concentration in learning, thorough in learning, willness in learning, and resilient in learning. Those two questionnaires are given during covid-19 quarantine.

Data obtained from the questionnaire of students' perception and interest of elearning during covid-19 quarantine is analyzed quantitatively by percentage. Questionnaire analysis of students' perception and interest is conducted with Likert scale model that has gradations from 1 to 5 . Specifically, $5=$ strongly agree, $4=$ agree, $3=$ neutral, 2 = disagree, and 1 = strongly disagree. Students' response to the instruments is calculated accordingly the score of the answer given. Afterward, researchers calculate the percentage of the answer.

To provide a clear description of the category of each variable, then the results of students' perception analysis of e-learning learning are converted into categories: very high, high, medium, low, and very low. Moreover, student interest in e-learning is 
divided into 5 categories, namely very not interested, not interested, quite interested, interested, and very interested. These criteria are described in table 1, table 2 , and table 3.

Table 1. Data conversion to a scale of five

\begin{tabular}{|c|c|}
\hline Score Interval & Category \\
\hline Lowest score $<$ score $<\mu-1,5 \alpha$ & Very Low \\
\hline$\mu-1,5 \alpha<$ score $<\mu-0,5 \alpha$ & Low \\
\hline$\mu-0,5 \alpha<$ score $<\mu+0,5 \alpha$ & Medium \\
\hline$\mu+0,5 \alpha<$ score $<\mu+1,5 \alpha$ & High \\
\hline$\mu+1,5 \alpha<$ score $<$ highest score & Very High \\
\hline
\end{tabular}

Table 1 above divides score into 5 categories. However, table that divides student's perception of e-learning can be seen on table 2 below

Table 2. Category of students' perception of e-learning

\begin{tabular}{|l|l|}
\hline Interval & Category \\
\hline $3-6$ & Very low \\
\hline $7-8$ & Low \\
\hline $9-10$ & Medium \\
\hline 11 & High \\
\hline $12-15$ & Very high \\
\hline
\end{tabular}

Table 3. Category of e-learning interest

\begin{tabular}{|c|c|}
\hline Interval & Category \\
\hline $9-18$ & Very not interested \\
\hline $19-24$ & Not interested \\
\hline $25-30$ & Quite interested \\
\hline $31-36$ & Interested \\
\hline $37-45$ & Very interested \\
\hline
\end{tabular}

\section{Result and Discussion}

Description of the results of the questionnaire of students' perceptions of the use of e-learning during covid-19 quarantine show that tendency of respondents in filling out questionnaires for each item. To make it easier in analyzing data, description is written for each indicator in independent variable. However, description is written at once. The results of the questionnaire are described as follows: 
Table 4. Categorizing students' perceptions of e-learning in the easiness indicator

\begin{tabular}{|c|c|c|c|}
\hline Score & Category & Frequency & Percentage \\
\hline 1 & $\begin{array}{c}\text { Strongly } \\
\text { disagree }\end{array}$ & 45 & $5,9 \%$ \\
\hline 2 & Disagree & 66 & $8,7 \%$ \\
\hline 3 & Neutral & 185 & $24,3 \%$ \\
\hline 4 & Agree & 259 & $34 \%$ \\
\hline 5 & Strongly agree & 206 & $27,1 \%$ \\
\hline
\end{tabular}

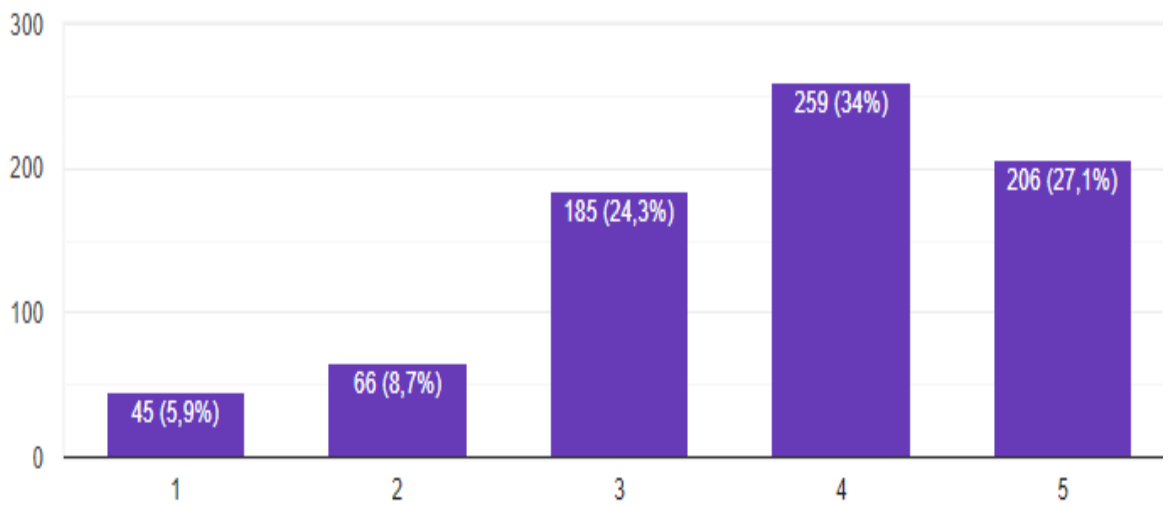

Figure 1. Percentage of students' perceptions in easiness indicator

From table 4 and figure 1 , it can be seen that there are 45 respondents $(5,9 \%)$ choose strongly disagree, 66 respondents $(8,7 \%)$ choose disagree, 185 respondents $(24,3 \%)$ choose neutral, 259 respondents (34\%) choose agree, and 206 respondents $(27,1 \%)$. As a result, it can be concluded that most students agree that Pamulang University e-learning website is easy to use.

Table 5. Categorizing students' perceptions of e-learning in the usefulness indicator

\begin{tabular}{|c|c|c|c|}
\hline Score & Category & Frequency & Percentage \\
\hline 1 & $\begin{array}{c}\text { Strongly } \\
\text { disagree }\end{array}$ & 98 & $12,9 \%$ \\
\hline 2 & Disagree & 138 & $18,1 \%$ \\
\hline 3 & Neutral & 247 & $32,5 \%$ \\
\hline 4 & Agree & 169 & $22,2 \%$ \\
\hline 5 & Strongly agree & 109 & $14,3 \%$ \\
\hline
\end{tabular}

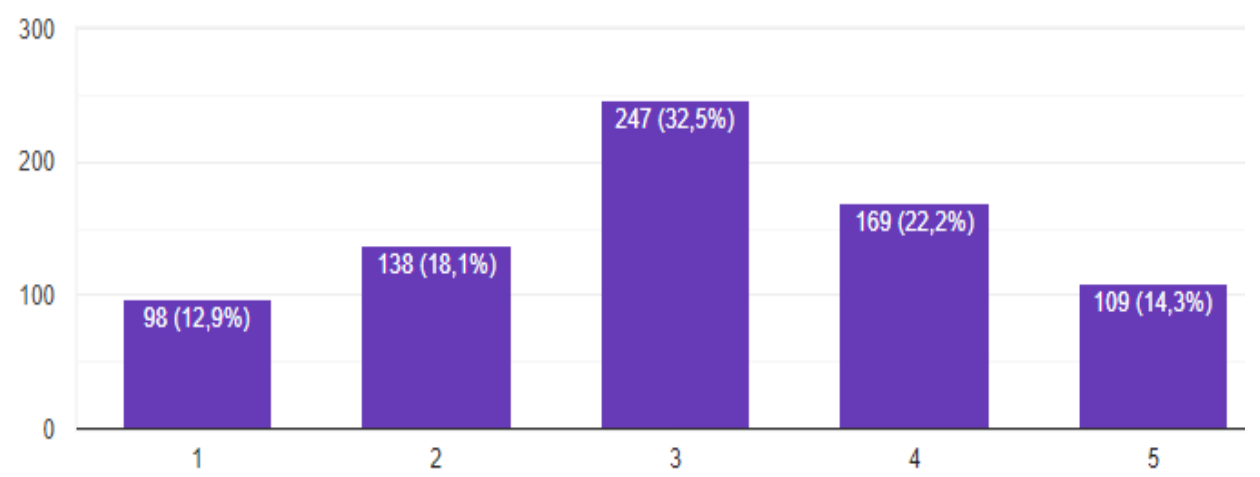

Figure 2. Percentage of students' perceptions in usefulness indicator 
From table 5 and figure 2, it can be seen that there are 98 respondents $(12,9 \%)$ choose strongly disagree, 138 respondents $(18,1 \%)$ choose disagree, 247 respondents $(32,5 \%)$ choose neutral, 169 respondents $(22,2 \%)$ choose agree, and 109 respondents $(14,3 \%)$. As a result, it can be concluded that most students neither agree or disagree that e-learning during covid-19 quarantine is useful in the learning process at Pamulang University.

Table 6. Categorizing students' perceptions of e-learning in the acceptance indicator

\begin{tabular}{|c|c|c|c|}
\hline Score & Category & Frequency & Percentage \\
\hline 1 & $\begin{array}{c}\text { Strongly } \\
\text { disagree }\end{array}$ & 151 & $19,8 \%$ \\
\hline 2 & Disagree & 208 & $27,3 \%$ \\
\hline 3 & Neutral & 244 & $32,1 \%$ \\
\hline 4 & Agree & 144 & $15 \%$ \\
\hline 5 & Strongly agree & 44 & $5,8 \%$ \\
\hline
\end{tabular}

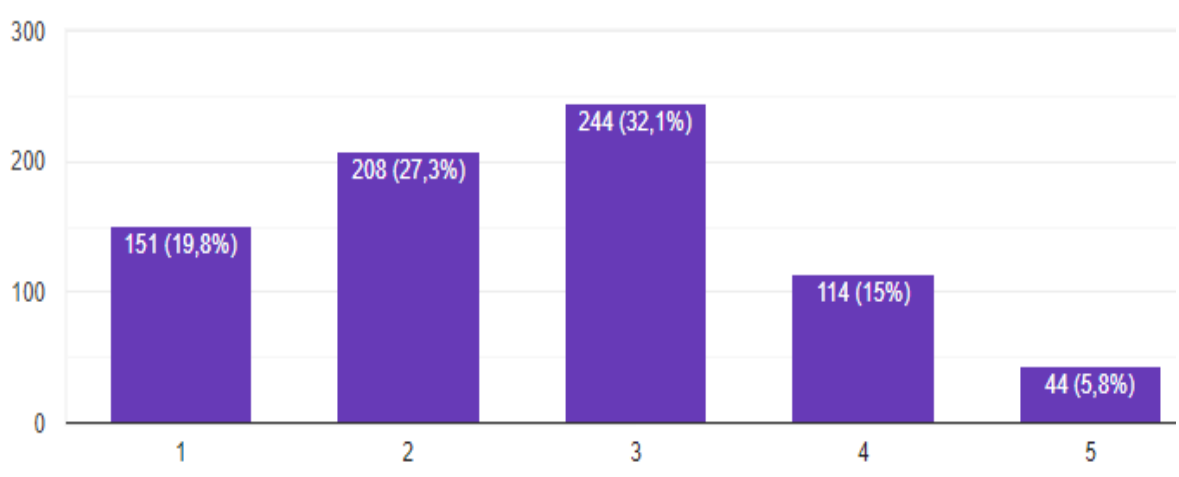

Figure 3. Percentage of students' perceptions in acceptance indicator

From table 6 and figure 3, it can be seen that there are 151 respondents $(19,8 \%)$ choose strongly disagree, 208 respondents $(27,3 \%)$ choose disagree, 244 respondents $(32,1 \%)$ choose neutral, 144 respondents $(15 \%)$ choose agree, and 44 respondents $(5,8 \%)$. As a result, it can be concluded that most students neither agree or disagree that students understand topic that explained by lecturers by using e-learning.

Table 7. Descriptive statistics of students' perceptions

\begin{tabular}{lc|c|c|r|c} 
& \multicolumn{6}{c}{ Descriptive Statistics } \\
& N & Min & Max & Mean & Std. Dev \\
\hline Perception & 761 & 3 & 15 & 9,34 & 3,02 \\
\hline Valid N & 761 & & & & \\
\hline
\end{tabular}


Data of students' perceptions can be seen on table 7 above. Analysis results of students' perception obtain minimal score is 3 , maximal score is 15 , mean score is 9,34 and standard deviaton is 3,02 .

Table 8. Categorizing students' perceptions of e-learning in all indicators

\begin{tabular}{|c|c|c|l|}
\hline Interval & Frequency & Percentage & Category \\
\hline $3-6$ & 135 & $17,74 \%$ & Very low \\
\hline $7-8$ & 155 & $20,37 \%$ & Low \\
\hline $9-10$ & 199 & $26,15 \%$ & Medium \\
\hline 11 & 82 & $10,78 \%$ & High \\
\hline $12-15$ & 190 & $24,97 \%$ & Very high \\
\hline
\end{tabular}

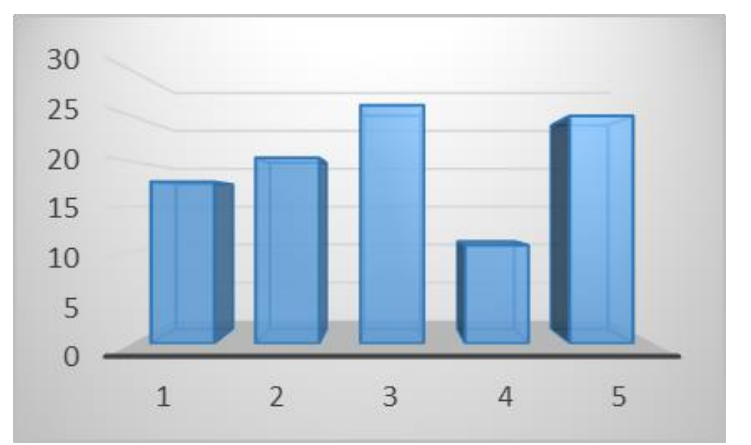

Figure 4. Bar of students' perceptions of e-learning in all indicators

From table 8 , it can be seen that there are 135 respondents $(17,74 \%)$ who have a very low perception of the use of e-learning during covid-19 quarantine, 155 respondents $(20,37 \%)$ who have a low perception of the use of e-learning during covid-19 quarantine, 199 respondents $(26,15 \%)$ who have a medium perception of the use of e-learning during covid-19 quarantine, 82 respondents $(10,78 \%)$ who have a high perception of the use of e-learning during covid-19 quarantine, 190 respondents $(24,97 \%)$ who have a very high perception of the use of e-learning during covid-19 quarantine.

Table 9. Descriptive statistics of e-learning interest

\begin{tabular}{lc|c|c|c|c} 
& \multicolumn{5}{c}{ Descriptive Statistics } \\
& N & Min & Max & Mean & Std. Dev \\
\hline Perception & 761 & 9 & 45 & 27,01 & 8,76 \\
\hline Valid N & 761 & & & & \\
\hline & & & & & \\
\hline
\end{tabular}

Data of e-learning interest can be seen on table 9 above. Analysis results of elearning interest obtain minimal score is 9 , maximal score is 45 , mean score is 27,01 and standard deviaton is 8,76 . 
Table 10. Categorizing e-learning interest of e-learning in all indicators

\begin{tabular}{|c|c|c|c|}
\hline Interval & Frequency & Percentage & Category \\
\hline $9-18$ & 126 & $16,56 \%$ & $\begin{array}{c}\text { Very not } \\
\text { interested }\end{array}$ \\
\hline $19-24$ & 173 & $22,73 \%$ & $\begin{array}{c}\text { Not } \\
\text { interested }\end{array}$ \\
\hline $25-30$ & 195 & $25,62 \%$ & $\begin{array}{c}\text { Quite } \\
\text { interested }\end{array}$ \\
\hline $31-36$ & 157 & $20,63 \%$ & Interested \\
\hline $37-45$ & 110 & $14,45 \%$ & $\begin{array}{c}\text { Very } \\
\text { interested }\end{array}$ \\
\hline
\end{tabular}

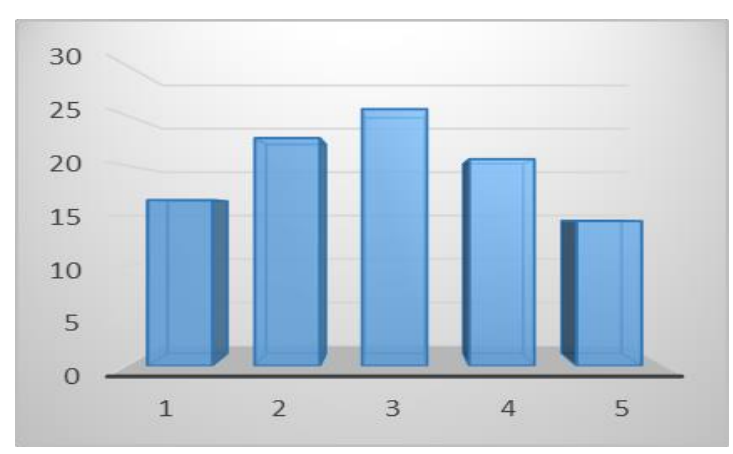

Figure 5. E-learning interest

From table 10, it can be seen that there are 126 respondents $(16,56 \%)$ who are not very interested toward e-learning during covid-19 quarantine, 173 respondents $(22,73 \%)$ who are not interested toward e-learning during covid-19 quarantine, 195 respondents $(25,62 \%)$ who are quite interested toward e-learning during covid-19 quarantine, 157 respondents $(20,63 \%)$ who are interested toward e-learning during covid-19 quarantine, 110 respondents $(14,45 \%)$ who are very interested toward e-learning during covid-19 quarantine.

The objective of the study is to investigate students' perceptions of the use of elearning during covid-19 quarantine. Based on the result of questionnaire shows that students' perceptions of the use of e-learning during covid-19 quarantine is medium. This shows that implementation of e-learning conducted in accounting department at Pamulang University is not implemented maximally yet. This can be contributed to study result conducted by Al-Juda (2017) stating that it is necessary for lecturers should properly plan, design and implement e-learning in order to conduct good e-learning.

In fact, Pamulang University has conducted e-learning since 2016. In other words, Pamulang University has enough experience to conduct e-learning. However, students' perceptions still prefer learn in the classrooms immediately to learn with online classes. 
Student' perception of easiness aspect is dominated by students who decide agree with item of the indicator. This result indicates that e-learning website that have been used in Pamulang University is easy to use. Moreover, students can access e-learning easily. E-learning conducted at Pamulang University can be accessed through a PC, laptop, or smartphone. students can discuss easily with lecturers and peers about teaching material. This is in accordance with research conducted by Mustarin \& Wiharto (2019) who state that e-learning can be easily conducted by students.

Student' perception of usefulness aspect is dominated by students who decide neutral with item of the indicator. This result indicates that most students neutral when they are asked usefulness of e-learning in the learning process at Pamulang University. Furthermore, because this research is conducted at accounting department then students generally doubt whether e-learning can help in understanding calculation in the course being taught. This is in accordance with research conducted by Yaniawati, Kariadinata, Sari, Pramiarsih, \& Mariani (2020) who state that e-learning applied to exact sciences is more challenging to implement.

Student' perception of acceptance aspect is dominated by students who decide neutral with item of the indicator. This result indicates that most students neutral when they are asked about understanding topics explained by lecturers via e-learning. Furthermore, students can access e-learning easily. E-learning conducted at Pamulang University can be accessed through a PC, laptop, or smartphone. students can discuss easily with lecturers and peers about teaching material. This is in accordance with research conducted by Islam, Beer \& Slack (2015) who state that students understand more material taught directly in the classroom than online learning.

Another objective of the study is to investigate e-learning interest during covid-19 quarantine. Based on the result of questionnaire shows that e-learning interest during covid-19 quarantine is quite interested. This shows that the application of e-learning conducted in accounting department at Pamulang University is not implemented interestingly yet. This can be contributed to study result conducted by Pavlovic, Vugdelija \& Kojic (2015) stating that lecturers should use social media tools such as wikis, blogs, video sharing, image, video meetings and video conferences as a powerful tools that can be used to enhace e-learning interest instead of classic e-learning platform. 


\section{Conclusion}

Based on the research and analysis that have been conducted, it can be concluded that

1. Students' perceptions of the use of e-learning during covid-19 quarantine in accounting department at Pamulang University is in medium category.

2. E-learning interest during covid-19 quarantine in accounting department at Pamulang University is in medium category.

Based on the research conclusions, the researchers suggest that lecturers at Pamulang University maximize all the features that have been provided on the Pamulang University e-learning website to improve the perceptions and interest of e-learning students in accounting department at Pamulang University. Furthermore, other researchers should conduct related to distance learning to improve learning outcomes especially after Covid19 outbreak. Nowadays, educators around the world implement distance learning to teach their students.

\section{Refernces}

Adiyudha, R. (2020, April 13). KPAI terima 213 aduan soal pembelajaran jarak jauh. Retreived from https://republika.co.id/berita/q8q6oq354/kpai-terima-213-aduansoal-pembelajaran-jarak-jauh

Al-Juda, M. Q. B. (2017). Distance Learning Students' Evaluation of E-Learning System in University of Tabuk, Saudi Arabia. Journal of Education and Learning, 6(4), 324-335. doi:10.5539/jel.v6n4p324

Hidayat, A. (2019). Student's Self-Concept Profiles in Problem Posing According to Cognitive Styles: Developing an Evidence Base for Best Practice of E-Learning In Mathematical Economics Course At Pamulang University. Jurnal Saintika Unpam: Jurnal Sains dan Matematika Unpam, 1(2), 158-165.

Hidayat, A., \& Prasetya, E. R. (2020). Penerapan teknologi dalam analisis perilaku belajar reflektif berbasis sistem android untuk meningkatkan pembelajaran elearning. Gammath: Jurnal Ilmiah Program Studi Pendidikan Matematika, 4(2), 79-87.

Hidayat, A., \& Sadewa, P. (2020). Pengaruh Penggunaan Aplikasi Eviews Terhadap Sikap Belajar dan Kemampuan Pemecahan Masalah Statistik. Edumaspul: Jurnal Pendidikan, 4(1), 321-328.

Islam, N., Beer, M., \& Slack, F. (2015). E-learning challenges faced by academics in higher education. Journal of Education and Training Studies, 3(5), 102-112.

Jury, M., Smeding, A., Stephens, N. M., Nelson, J. E., Aelenei, C., \& Darnon, C. (2017). The experience of low-SES students in higher education: Psychological barriers to 
success and interventions to reduce social-class inequality. Journal of Social Issues, 73(1), 23-41.

Mustarin, A., \& Wiharto, M. (2019, April). Persepsi mahasiswa terhadap penggunaan program e-learning berbasis LMS pada Mata Kuliah Teknologi Budidaya Perikanan. In Seminar Nasional LP2M UNM.

Nikolopoulou, K., \& Gialamas, V. (2015). Barriers to the integration of computers in early childhood settings: Teachers' perceptions. Education and Information Technologies, 20(2), 285-301.

Pavlovic, M., Vugdelija, N., \& Kojic, R. (2015). The Use of Social Networks for Elearning Improvement. Hellenic Journal of Music, Education and Culture, 6(1).

Puspaningtyas, N. D. (2019). Berpikir Lateral Siswa SD Dalam Pembelajaran Matematika. Mathema: Jurnal Pendidikan Matematika, 1(1), 24-30.

Yaniawati, P., Kariadinata, R., Sari, N. M., Pramiarsih, E. E., \& Mariani, M. (2020). Integration of e-Learning for Mathematics on Resource-Based Learning: Increasing Mathematical Creative Thinking and Self-Confidence. International Journal of Emerging Technologies in Learning (iJET), 15(06), 60-78. 